\title{
Applied Economics
}

\section{The determinants of privatization prices: evidence from Turkey}

\section{Kerim Peren Arin \& Cagla Okten}

To cite this article: Kerim Peren Arin \& Cagla Okten (2003) The determinants of privatization prices: evidence from Turkey, Applied Economics, 35:12, 1393-1404, DOI: $10.1080 / 0003684032000100391$

To link to this article: http://dx.doi.org/10.1080/0003684032000100391

$$
\text { 曲 Published online: } 05 \text { Oct } 2010 .
$$

Submit your article to this journal

Џll Article views: 88

Q View related articles $\leftarrow$

4 Citing articles: 5 View citing articles 


\title{
The determinants of privatization prices: evidence from Turkey
}

\author{
KERIM PEREN ARIN and CAGLA OKTEN*: \\ Department of Commerce, Massey University, Auckland, New Zealand and \\ $\ddagger$ Department of Economics, Bilkent University, Bilkent, Ankara 06800 Turkey
}

This paper analyses the determinants of privatization prices in a multi-industry study using a sample of 68 recently privatized firms from Turkey. Results show that revenue and market characteristics are significant determinants of privatization prices while current cost and profit indicators are not. It is argued that potential buyers regard these state firms as inefficient, therefore do not take into consideration their current costs and profits in determining their value. When the dependent variable is altered by dividing the firm's privatization price by the firm's sales (revenues), it is found that sales-adjusted privatization prices are responsive to firms' profit margins. However, this result does not hold when the sample is restricted to a single industry. Profit margins along with other profitability and firm efficiency measures are no longer significant determinants of sales-adjusted privatization prices in the cement industry analysis. Unexploited production opportunities measured by capacity utilization ratios, and complete private ownership resume a more important role.

\section{INTRODUCTION}

Generating revenue is one of the fundamental objectives of privatization. Yet, very little is known about how well one achieves this objective and what determines privatization revenues. How do firm and market characteristics affect privatization prices? Should government adopt restructuring investments prior to privatization? Is there a learning effect in the privatization process?

This paper uses firm-level data to answer these important questions and analyse the determinants of privatization prices in Turkey. The effects of firm, market and auction characteristics on privatization prices are measured using a sample of 68 firms from six different industries, namely cement, dairy products, ports, marinas, airport services and the heavy manufacturing industry.

The study focuses next on a single industry, the cement industry, and analyses the determinants of privatization prices for the 24 privatized cement plants for several reasons. First, inter-industry studies may suffer from problems associated with unobserved heterogeneity at the industry level, and the analysis of a single sector is useful to check the robustness of results. Second, all public cement plants that ever existed were privatized between 1989 and 1998 and the sample includes all of these plants. Therefore, one is able to look at a more complete picture of privatization and avoid the problem of endogeneity associated with sample selection. Third, a more detailed analysis of the determinants of privatization prices is possible due to increased data availability for this industry. Fourth, Turkey is the largest cement producer in Europe and seventh in the world (OAIB, Cimento Sektoru Raporu, 1998).

Privatization in Turkey started around 15 years ago, in order to relieve the state from the burdens of inefficient state industries and create revenue for the government. Since then, numerous state companies have been sold to the private sector. Most of the privatizations in the sample were realized through block sales - closed bid auctions - and through a combination of block sales and public offerings in a few cases.

Privatization has received considerable attention in recent years. Megginson and Netter (2001) provide an

*Corresponding author. E-mail: cokten@bilkent.edu.tr 
excellent survey paper of the privatization literature. A major portion of this literature focuses on changes in firms' efficiency as a result of privatization. Literature on the determinants of privatization prices is relatively sparse. A branch of the finance literature concentrates on the under-pricing of Initial Public Offerings (IPOs) of public enterprises. For instance, a recent study by Huang and Levich (1998) finds that initial returns on privatization IPOs are significantly less than seasoned offerings.

To the authors' knowledge, there is only one other empirical study that analyses the effects of firm characteristics and auction process variables on privatization prices. Lopez-De-Silanes (1997) examines 236 Mexican firms, which were privatized between the years 1983 and 1992. This study used a very heterogeneous sample of firms from many different industries. It is possible that unobserved industry heterogeneity might have influenced results. Since there are data for a sizeable number of firms from a single industry one will be able to analyse whether the results are applicable when this industry is focused on and problems associated with unobserved heterogeneity at the industry level are avoided.

It is found that the number of bidders increases privatization prices by increasing the level of competition in these auctions as Lopez-De-Silanes (1997) finds. However, there are notable differences on how firm characteristics affect privatization prices. While his findings indicate that low profitability of state-owned prices explain the low price paid, it is found that revenues affect privatization prices, not profits. The reason is straightforward: what fundamentally determines the privatization price is the expected future profit of the firm. Potential buyers discount firms' current costs since they believe that these firms are inefficient. Current costs and hence profits do not affect privatization prices because they do not reflect expected future profits, whereas revenue and market characteristics are good indicators for future profitability.

When the dependent variable is altered by scaling the raw privatization price with the firm's sales (revenues) it is found that firm's profit margin has a positive and significant effect on the sales adjusted privatization price similar to Lopez-De-Silanes. However, when a single industry (cement industry) is concentrated on, this variable is no longer found to be significant. Therefore, the interpretation for the effect of this variable is different from Lopez-DeSilanes. One would argue that profit margins measure the differences in market power of firms in different industries (market structures) rather than differences in firm efficiency and that is why profit margins are significant in the multiindustry study and insignificant in the single (cement) industry analysis.

In the focus on the cement industry it is found that unexploited production opportunities measured by a low capacity utilization ratio and complete private ownership become significant determinants of the sales-adjusted privatization price.

Restructuring investment is initially found to have a negative effect on the sale price. However, when the number of bidders is included in the regression, restructuring investment is no longer significant. It is argued that restructuring investment might be measuring for the number of bidders in the absence of this control. In other words, firms that are expected to attract few buyers undergo restructuring to increase their prospects.

The following section describes the institutional background of privatization in Turkey in general and of the cement industry in particular. Section III explains the theoretical framework of the analysis. Section IV presents the data and the methodology used. The econometric results are presented and discussed in Section V. Section VI offers concluding thoughts and directions for future research.

\section{INSTITUTIONAL BACKGROUND}

\section{Privatization in Turkey}

Historically, Turkey has had a long experience relying heavily on state owned enterprises (SOEs). SOEs were established during the 1930s by the government to jump-start the economy that collapsed with the end of the Ottoman era in 1923. Over the years SOEs grew enormously, leaving the control of a large section of the economy to bureaucrats and politicians. Politicians exploited SOEs to provide jobs to their constituents at the expense of consumers, who were faced with higher prices. Consequently, in the 1980s, SOEs began to be perceived negatively due to poor financial performance, overstaffing, dependence on subsidies, protected markets and corruption (Ficici, 2001).

After a Military Regime (1980-1983), the first party that came to power under the leadership of Prime Minister Turgut Ozal was the Motherland Party (ANAP). Ozal was heavily influence by Margaret Thatcher's policies that promoted reducing the state's role in the economy. Privatization came into the political agenda first with Ozal's trade and capital account liberalization programme in 1984.

Despite this initial enthusiasm, however, Turkey realized only a small portion of its privatization potential. Privatization of state owned enterprises has so far been concentrated in a few industries. Between 1986 and 1998 only $\$ 4.5$ billion worth of assets, representing less than $10 \%$ of the outstanding state owned assets could be divested (Ficici, 2001). The privatization reforms have not been fully carried out as intended, due to a lack of legal framework and conflicting laws in the country's constitution with regard to privatization. 


\section{Privatization process in the cement industry}

The first cement plant in Turkey was established in 1911 by a private firm. By 1950, four new private plants had been built. Only after 1950 did the cement industry develop on a large scale by means of a government initiative. A public enterprise, CISAN (Turkish acronym for Turkish Cement Industry Co. later named CITOSAN), was established in 1953 to build 15 plants in various regions. Before privatization of the cement plants started in 1989, the public share in the cement industry was nearly $40 \%$ (Saygili and Taymaz, 2000). It is believed that each company was able to exercise some monopoly power within its hinterland (Ertuna, 1998), most probably due to the distance between firms and the lack of proper transportation facilities in the public sector.

In 1986, A French company, Sema-Metra Conceil was contracted by the Turkish government and the World Bank to prepare two reports, one on the structural Regulation of the Cement Sector and Privatization and the other on the plan for the Reorganization of CITOSAN. In the latter report, Sema-Metra Conceil suggested that plants in the West be privatized first since they could be as profitable as private plants, and recommended that the eastern plants be restructured prior to privatization. The report also suggested privatization on a plant-by-plant basis, as the sale of the state firm as a single entity, may have led to an unhealthy monopoly (Tallant, 1993). In 1986, there was a major change in the economic environment of the cement plants. Prior to 1986, the Turkish Cement Producers' Association (TCPA) set prices and market areas for all cement companies, however, after 1986 firms were encouraged to operate independently and maximize profits. Sema-Metra's first report might partially have led to this change.

Privatization in the cement industry started in 1989, with the initial sale of five factories to the French firm Cement Francais (SCF). By 1998, the sale of 24 public firms was completed. The recommendations of the Sema-Metra report were taken into consideration, and the western plants were privatized first, with two exceptions, Denizli and Lalapasa. These two public firms were established in 1987 and 1991 respectively, in order to meet the growing demand in the western regions. It may also be the case that the privatization of the eastern plants were delayed, as the eastern region suffered from unemployment and terrorism throughout the 1990s, and public enterprises were used as a means of employment.

Privatization of the cement plants was carried out under the Privatization Administration of Turkey. Most of the privatizations were realized through block sales - closedbid auctions - and through a combination of block sales and public offerings in a few cases. Public sector employment was guaranteed to all workers that lost their jobs because of privatization (Privatization in Turkey,
Ozellestirme Idaresi Baskanligi). Hence there was no disposal cost of workers for the buyers of the privatized firms.

Today, the Turkish cement industry consists of 39 private plants, some owned by giant industrial holdings and others by small one-plant companies. There are four foreign investors in the industry, namely French firms Ciment Francais, Lafarge Coppee, Ciment Vicat and German Heidelberger Zement/CBR. Cement consumption continues to grow at sound levels and Turkey continues to be a major exporter of cement. According to the report of Central Anatolian Board of Export, in 1998, Turkey was the largest cement producer in Europe and seventh in the world. (OAIB, Cimento Sektoru Raporu).

\section{THEORETICAL FRAMEWORK}

This study sets out to explain two variables. The first one is the raw privatization price and the second one is the sales and share adjusted privatization price, which is constructed by scaling the raw privatization price by the firm's revenues and percentage of shares privatized.

\section{Determinants of raw privatization prices}

Assuming that auctions are competitive and there is no significant corruption, one would expect privatization prices to reflect expected future profits. Current profits will have a positive effect on the privatization price to the extent that they reflect future profits. If state owned firms are inefficient because they employ excess labour, misuse their resources or simply over-inflate their budgets, one does not necessarily expect current profits to reflect expected future profits as current costs will not reflect future costs.

\section{Firm and industry characteristics}

If state owned firms are inefficient, current revenue and market characteristics might have more valuable information than current costs in reflecting future profits. Hence, we expect sales, production level and growth rate to have positive effects on privatization prices as they measure for the market size and potential available to these firms.

Expected costs will depend on expected labour costs and future investment. If state owned firms employ excess labour and there are costs to firing workers due to strong unions, etc., one would expect number of workers to decrease the privatization price. If there are no disposal costs of excess labour on the other hand, current number of workers is not likely to have any effect. In the case of the cement and dairy industries, the Turkish government guaranteed public sector employment to all workers who lost their jobs as a result of privatization, and hence there was no displacement cost of labour for the new owner for the 
majority of firms in the sample. Hence one does not expect the number of workers to have any effect on the privatization price for these industries.

Capacity utilization ratio might be a good candidate measure of the firm's expected future investment. This ratio is the percentage of the optimal capacity utilized in the production process and optimal capacity is the minimum efficient scale. A high value of this variable indicates that increases in production in the near future are likely to start increasing the average costs and therefore the firm will need to invest in capacity. Hence, if the market has a strong growth potential, then the capacity utilization ratio is expected to have a negative effect on price. Firms may also value a low capacity utilization rate because they value excess capacity to deter entry or to respond to fluctuations in demand. If the market is not expected to grow and current production is a good indicator of future production, however, then a high capacity utilization rate is better as average costs fall as the firm increases its capacity towards the minimum efficient scale. Hence a priori, the effect of capacity utilization rate on privatization prices depends on whether firms plan to increase production in the near future.

\section{Auction process variables}

The level of competition in auctions is expected to affect the privatization price (Milgrom, 1987; Laffont, 1994). The auction theory states that the sale price should increase as the number of bidders increases since this would increase the level of competition. Therefore, we expect privatization price to be an increasing function of the number of bidders that participate in the auction.

The effect of the length of the auction on the sale price is not that clear. It may have a negative effect on sale price if the announcement of privatization triggers deterioration of incentives and performance, similar to that of firms in financial distress (Altman, 1984; Wruck, 1990). If the announcement of privatization increases public's attention on the firm's performance, however, then the firm's managers might increase their efforts to acquire a good reputation (Caves, 1990).

\section{Government decisions}

It is important to assess what the role of government should be in the privatization process. On one hand, government may increase the privatization price of the firm by adopting restructuring policies prior to the privatization. On the other hand, the existence of restructuring policies may signal the low productivity or the backward technology of the firm, and decrease the privatization price.

Government also decides on the amount of shares that are privatized. One expects the percentage of the firm that is privatized to have a positive effect on the raw privatiza- tion price. The percentage of the privatization ranges from 40 to $100 \%$ in the complete data set and 95.6 to $100 \%$ for the cement industry sample. The importance of complete ownership on the sales and share adjusted privatization price is also tested by constructing a dummy variable, which is equal to one if the firm were privatized in totality.

Finally, there can be a learning process for the government during the privatization process. If there exists a learning effect, the inflation corrected sale value of the firms privatized later should be higher than those that were privatized earlier. However, according to SemaMetra Conceil's report, more profitable/valuable plants in western regions were privatized first. If this is the case, firms that are privatized later may fetch a lower price.

\section{Determinants of sales and share adjusted privatization prices}

Using the sales and share adjusted privatization price as the dependent variable allows one to focus on the effects of firm profitability and efficiency variables in determining privatization prices once firms' revenue characteristics are accounted for. In other words, the goal is to analyse what determines privatization prices once one accounts for firm's 'value' approximated by the firm's sales. In addition to firm's profits, the effects of the firm's profit margin and labour productivity are measured in determining the sales adjusted privatization price. Profit margin, constructed by dividing profits by the firm's revenues, may be interpreted as a measure of market power or firm efficiency. In fact, in a constant cost industry, assuming that all costs are variable in the long run, it is the measure of a firm's ability to charge a price above marginal cost. To the extent that state owned firms maximize an objective function, which puts some weight on the firms' profits, state owned firms' current profit margins will reflect future profit margins and hence influence the privatization price.

Labour productivity is a measure of firm efficiency in the analysis of the cement industry since unit of output is constant across firms. To the extent that current firm efficiency will reflect future firm efficiency, we would expect labour productivity to have a positive influence on the sales adjusted privatization price.

The expected effects of auction process variables and government decisions such as restructuring investment, the number of bidders, length of auction, time of privatization on the sales adjusted privatization prices are same as discussed above.

\section{DATA AND METHODOLOGY}

Our data set of 68 firms is constructed by using the official statistics of the Privatization Administration of Turkey, and includes 24 cement factories, 29 dairy product plants, 
four ports, three marinas, two airline service firms, and six heavy industry manufacturers like mining and metal firms, which were privatized in Turkey between the years 1989 and 1998. Sample size is reduced in certain specifications as one lacks data on profits for some of these firms.

The Privatization High Council is the ultimate decisionmaking body for privatization, under the chairmanship of the Prime Minister. Sales of public companies are through domestic or international offerings, block sales to persons and/or entities, block sales including deferred public offerings, sales to employees, sales on the stock exchange by standard and special offers, and finally sales to securities investment funds and/or securities investment partnerships by taking into consideration the prevailing conditions of the companies (Privatization in Turkey, Ozellestirme Idaresi Baskanligi). In the sample, 65 out of 68 firms were sold through block sales. The remaining three firms were sold through a combination of block sale and public offerings.

In the first set of regressions, the dependent variable is the raw privatization price of the firm, corrected for inflation using the official CPI statistics of Federal Reserve Bank of Minneapolis taking 1987 as the base year.

In the second set of regressions, the determinants of privatization prices given the firms' sales are analysed by using the sales (and share) adjusted privatization price as the dependent variable. This sales-adjusted privatization price is obtained by dividing the standardized sale price by the total sales (revenues) of the firm in the year prior to privatization and by the percentage of shares privatized.

The goal in this set of regressions is to explore whether differences in firm efficiencies and market power measured by the level of profit, labour productivity and profit margins, are reflected in the privatization price given the 'value' of the firm approximated by its sales.

The description of the independent variables and their expected effects on privatization prices are presented in Table 1. Table 2 presents descriptive statistics for all variables of interest, for the complete sample. Table 3 represents the summary statistics for the cement industry sample. Regressions are estimated using an Ordinary Least Squares method in all regressions except one, where government's restructuring investment is instrumented with lagged values of this variable in a two-stage least squares estimation. Standard errors are White (1980) corrected.

\section{EMPIRICAL RESULTS AND DISCUSSION}

Results for the complete sample are presented in Table 4A where the dependent variable is the inflation-adjusted privatization price. The findings show that the main determinant of the privatization prices is the amount of sales before privatization. The amount of sales has a positive and a significant effect on the privatization price (Regressions 1 through 3), while net profits (Regression 3), capacity utilization ratio and number of workers are found to be insignificant (Regression 1). The number of workers does not have a significant effect because the Turkish government guaranteed public sector employment to all workers who lost their jobs as a result of privatization in the dairy and cement industries, and hence there was no displacement cost of labour for the new owner for the vast majority of firms in the sample.

These results indicate that the buyer cares about the firm's revenues and not its profits. It is believed that current costs and profits do not reflect expected future profits because buyers view state owned firms as inefficient. ${ }^{1}$

There seems to be a considerable amount of industry heterogeneity in our sample. The dummy variable is found to be negative and significant (Regression 1) for the dairy industry and positive and significant for marinas (Regressions 2 and 3). It is not found that privatization year has any significant effects on the raw privatization price (Regression 2).

Next, using the same dependent variable, the cement industry is focused on in order to (1) avoid the problems associated with unobserved heterogeneity at the industry level, (2) conduct a more through analysis as we have data available for a wider range of variables, and (3) avoid the problem of endogeneity associated with sample selection since all public cement plants were privatized and we have data for all of them.

Regression results for the cement industry are presented in Table 4B. Results show that proportion of the firm privatized, production level, production growth rate have positive and significant effects on privatization price, while net profits and number of workers are found to be insignificant (Regressions 1 and 2). Production level measures the size of the market available for these regional monopolies, while growth rate of production indicates the growth potential of this market. ${ }^{2}$

Although the proportion of the firm privatized has a narrow range - between 95.6 and $100 \%$ - it still turns out to be an important determinant of sale value indicating the importance of complete private ownership.

\footnotetext{
${ }^{1}$ Okten and Arin (2002) find that cement firms that are analysed in this paper, decrease their number of workers significantly after privatization indicating the existence of excess labour in the public sector.

${ }^{2}$ Other variables such as capacity and sales were also used instead of firm's output to measure for the market size available to the firm. Results essentially remained the same.
} 
Table 1. Description of independent variables $\dagger$

\begin{tabular}{|c|c|c|}
\hline Variable & Description & $\begin{array}{l}\text { Expected effect } \\
\text { on sale price }\end{array}$ \\
\hline \multicolumn{3}{|c|}{ Panel A: Firm and industry characteristics } \\
\hline Sales & $\begin{array}{l}\text { The sales (revenue) amount one year before privatization, } \\
\text { measured in dollars }\end{array}$ & Positive \\
\hline Number of workers & The number of employees one year before the privatization & Insignificant \\
\hline Net profit & $\begin{array}{l}\text { The net profits of the firm in dollars, one year before the } \\
\text { privatization, corrected for inflation }\end{array}$ & $\begin{array}{l}\text { Positive or } \\
\text { Insignificant }\end{array}$ \\
\hline Profit margin & $\begin{array}{l}\text { Net profits of the firm, one year before privatization, } \\
\text { corrected for inflation }\end{array}$ & Positive \\
\hline Labour productivity & $\begin{array}{l}\text { The output of the firm (in tons) divided by the number of employees, } \\
\text { one year before privatization }\end{array}$ & Positive \\
\hline \multicolumn{3}{|c|}{ Panel B: Auction process variables } \\
\hline Number of bidders & The number of bidders admitted to join the final auction by government & Positive \\
\hline The length of auction & $\begin{array}{l}\text { The number of days between the first public announcement of privatization } \\
\text { and the completion of the sale. }\end{array}$ & Ambiguous \\
\hline \multicolumn{3}{|c|}{ Panel C: Government decisions } \\
\hline Percentage privatized & The percentage share of the firm that is sold to the private sector & Positive \\
\hline Complete ownership dummy & $=1$ if $100 \%$ of the firm is privatized & Positive \\
\hline Restructuring investment & $\begin{array}{l}\text { Restructuring investment by the government in dollars, one year before the } \\
\text { privatization, corrected for inflation }\end{array}$ & Ambiguous \\
\hline Privatization year & The year that the public firm was sold to the private sector & Ambiguous \\
\hline
\end{tabular}

$\uparrow$ All values are corrected for US inflation by using the official CPI statistics of Federal Reserve Bank of Minneapolis. $1987=1.00$ is used as a base year. Turkish Lira Values are transformed into Dollar values by using Lira/Dollar exchange rate based on bid prices of Turkish Central Bank.

It is found that the capacity utilization ratio has a negative and significant effect on the privatization price, in contrast to the inter-industry study where this variable was not found to be significant. This result is intriguing and there can be several reasons why potential buyers would value a low utilization rate as discussed in the theoretical framework section. One possible explanation for this finding is that capacity utilization ratio might be correlated with the growth rate of the market. Government might have considered this growth rate when it made the capacity choice for these firms. For example, if a market had a high expected growth rate, government might have initially chosen a high capacity level and therefore a low capacity utilization ratio for the cement plant.

In order to address this possibility, the population growth rate of the city where the cement factory is located is included in the regression as well as the growth rate of production (Regression 3). Population growth rate of the city measures for the expected growth potential of the market, and has a positive though insignificant effect on privatization price. It is interesting to note that capacity utilization ratio is no longer significant in this regression supporting the argument that a high utilization ratio is more prevalent for markets with low growth potential. ${ }^{3}$

It is found that the privatization year has an insignificant effect on sale price (Regression 3). This result does not support the learning argument, however, if privatization year is endogenous to the expected privatization price, in other words if firms that are easier to sell or more likely to fetch a high price are privatized first, then one would expect lower prices for later privatizations. Indeed, Sema-Metra Conseil Report suggested that more profitable western

\footnotetext{
${ }^{3}$ Capacity utilization ratio is negatively correlated with population growth rate at $10 \%$ significance level, further strengthening
} this argument. 
Table 2. Descriptive statistics for the complete sample

\begin{tabular}{|c|c|c|c|c|c|}
\hline Variable & $N$ & Mean & Std. Dev. & Min & Max \\
\hline Privatization Price & 68 & 143108.3 & 179182.6 & 739.8294 & 802358.3 \\
\hline Sales Adjusted Privatization Price & 66 & 4.266444 & 7.202772 & 0.2287631 & 34.71449 \\
\hline Proportion Privatized & 68 & 98.03453 & 8.597328 & 40 & 100 \\
\hline Total Privatization Dummy & 68 & 0.7352941 & 0.4444566 & 0 & 1 \\
\hline Production & 53 & 173296.7 & 208726.3 & 124 & 727602 \\
\hline Capacity Utilization Ratio & 62 & 59.33871 & 39.29653 & 1.66 & 179.91 \\
\hline Number of Employees & 68 & 218.0588 & 332.0999 & 4 & 2053 \\
\hline Labour Productivity & 24 & 1315.958 & 497.2238 & 792 & 2917 \\
\hline Dairy Products Dummy & 68 & 0.4264706 & 0.498241 & 0 & 1 \\
\hline Ports Dummy & 68 & 0.1029412 & 0.3061414 & 0 & 1 \\
\hline Cement Dummy & 68 & 0.3529412 & 0.4814377 & 0 & 1 \\
\hline Services Dummy & 68 & 0.0294118 & 0.1702139 & 0 & 1 \\
\hline Sales & 68 & 60809.66 & 76154.29 & 0 & 282258.1 \\
\hline Profits & 38 & 8797.14 & 36216.3 & -38898.79 & 168980.4 \\
\hline Number of Bidders & 18 & 2.944444 & 2.838231 & 1 & 10 \\
\hline Privatization Year & 68 & 1994.588 & 2.319517 & 1989 & 1998 \\
\hline Labour Productivity & 53 & 661.1842 & 691.0316 & 12.4 & 2916.739 \\
\hline Restructuring Investment & 24 & 5763.705 & 8001.413 & 0 & 29527.59 \\
\hline Sales per Capita & 68 & 298.4054 & 239.7006 & 0 & 1329.29 \\
\hline Profit Margin & 38 & -0.015258 & 0.7852719 & -3.239727 & 2.720792 \\
\hline
\end{tabular}

Table 3. Descriptive statistics for the cement industry

\begin{tabular}{|c|c|c|c|c|c|}
\hline Variable & $N$ & Mean & Std. Dev. & Min & Max \\
\hline Privatization Price & 24 & 265.0156 & 162.8225 & 22.3072 & 802.3583 \\
\hline Sales Adjusted Privatization Price & 23 & 2.200449 & 1.310716 & 0.7150006 & 6.660847 \\
\hline Proportion privatized & 24 & 99.63583 & .962695 & 95.46 & 100 \\
\hline Labour Productivity & 24 & 374806.9 & 143875 & 102000 & 727602 \\
\hline Capacity Utilization Ratio & 24 & 79.16667 & 15.67514 & 50 & 109 \\
\hline Employment & 24 & 291.5417 & 75.73924 & 72 & 408 \\
\hline Profit & 24 & 804429.2 & 2370783 & -6127637 & 5429272 \\
\hline Number of Bidders & 18 & 2.944444 & 2.838231 & 1 & 10 \\
\hline Auction Length & 19 & 266.3158 & 169.5465 & 58 & 478 \\
\hline Population Growth Rate & 24 & 7.897083 & 14.33121 & -13.49 & 39.4 \\
\hline Privatization Year & 24 & 1992.958 & 2.773777 & 1989 & 1998 \\
\hline Profit Margin & 24 & 0.0846934 & 0.2785005 & -0.2762347 & 1.258642 \\
\hline
\end{tabular}

plants be privatized first and this suggestion was mostly followed. Hence an insignificant coefficient on the privatization year may actually indicate that there is a learning effect if more profitable firms located in vibrant western markets were sold first and all else equal, these firms would have fetched a higher price.

The restructuring investment by the government prior to privatization appears to have a negative effect on the privatization price (Regression 4). This result supports Lopez-De-Silanes (1997), who finds that the direct costs of prior restructuring policies absorb the sale price. Lopez-De-Silanes (1997) argues that this is due to the fact that restructuring measures cause delays in privatization. However, there can also be an endogeneity problem with this finding. If firms that are more difficult to privatize are subject to more restructuring measures then one would also find a negative relationship between sale price and restructuring investment. In order to address this possible endogeneity problem, we use a two-stage least squares method and instrument restructuring investment with investment undertaken two years prior to the privatization year and other explanatory variables. Results essentially remain the same (Regression 5).

When we include the number of bidders as well as the restructuring investment in the regression however, restructuring investment becomes positive though not significant (Regression 6). The change in the significance of restructuring investment when number of bidders is included in the 
Table 4A. Determinants of privatization prices $\dagger$ : Complete sample. Dependent variable: Privatization Price

\begin{tabular}{|c|c|c|c|}
\hline & (1) & (2) & (3) \\
\hline \multirow{4}{*}{$\begin{array}{l}\text { Proportion } \\
\quad \text { Privatized } \\
\text { Sales }\end{array}$} & 3.956 & $10.658 * * *$ & $7.212 * *$ \\
\hline & $(0.85)$ & $(3.41)$ & $(2.59)$ \\
\hline & $0.0008 * *$ & $0.0012 * * *$ & $0.0009 * *$ \\
\hline & $(2.29)$ & $(3.71)$ & $(2.29)$ \\
\hline \multirow{2}{*}{$\begin{array}{l}\text { Cap. Utilization } \\
\text { Ratio }\end{array}$} & -0.253 & & \\
\hline & $(-0.64)$ & & \\
\hline $\begin{array}{l}\text { Number of } \\
\text { Workers }\end{array}$ & $\begin{array}{l}-0.145 \\
(-1.00)\end{array}$ & & \\
\hline \multirow[t]{2}{*}{ Cement Dummy } & -66.169 & 60.301 & 15.874 \\
\hline & $(-0.58)$ & $(0.47)$ & $(0.16)$ \\
\hline \multirow[t]{2}{*}{ Dairy Dummy } & $-269.51 * *$ & -105.94 & \\
\hline & $(-2.03)$ & $(0.91)$ & \\
\hline \multirow[t]{2}{*}{ Port Dummy } & & -42.411 & 1.591 \\
\hline & & $(-0.38)$ & $(0.01)$ \\
\hline \multirow[t]{2}{*}{ Marina Dummy } & -42.45 & $280.78 *$ & $260.55^{*}$ \\
\hline & $(-0.25)$ & $(1.81)$ & $(1.70)$ \\
\hline \multirow[t]{2}{*}{ Services Dummy } & & $317.73 *$ & 151.91 \\
\hline & & (1.83) & $(0.99)$ \\
\hline Profit & & & 0.0013 \\
\hline \multirow[t]{2}{*}{ Privatization Year } & & 22.14 & \\
\hline & & $(1.60)$ & \\
\hline \multirow[t]{2}{*}{ Intercept } & -112.84 & -45139.56 & $-604.70^{*}$ \\
\hline & $(-0.23)$ & $(-1.61)$ & $(-1.94)$ \\
\hline$R$-squared & 0.54 & 0.56 & 0.26 \\
\hline $\begin{array}{l}\text { Number of } \\
\text { observations }\end{array}$ & 62 & 68 & 38 \\
\hline $\begin{array}{l}\text { Estimation } \\
\text { method }\end{array}$ & OLS & OLS & OLS \\
\hline
\end{tabular}

$\dagger$ Dependent variable is the privatization price in dollars corrected for inflation and scaled by 1000 .

$t$-statistics are given in parentheses.

*Significant at the $10 \%$ level

**Significant at the 5\% level

$* * *$ Significant at the $1 \%$ level

regression is troubling. There can be two reasons for this change: (1) the relationship between sales price and restructuring investment is not robust and a reduction of sample size due to lack of data on the number of bidders for six firms, is enough to make investment insignificant; (2) relationship between privatization price and restructuring investment is endogenous, government undertakes this investment only for firms that are expected to attract few potential buyers.

We believe there is some truth in both explanations. We re-did regression 6 excluding the number of bidders but restricting the regression to those observations for which this variable is available. Restructuring investment is positive but very insignificant in this regression, which is available upon request. We also contacted buyers of these state firms, of which two responded. One buyer who actually bought two of the plants indicated that government restructuring investment was not significant and did not affect their bids. This buyer also indicated that market size of the firm was the most important determinant of their valuation, providing further support for the results on the importance of market characteristics. The second buyer indicated that they regarded government's restructuring investment as a sign for the backward technology of the firm, supporting the argument that government's investment is endogenous to the value and hence the sale price of the firm.

It is found that the number of bidders has a positive and significant effect on the sale price as implied by economic theory. Auction length on the other hand, is not a significant determinant of privatization prices.

Regressions presented in Table 4A and 4B provide evidence that potential buyers value revenue characteristics in pricing public firms instead of cost or profit characteristics. However to understand the privatization process better, one has to understand what determines the privatization price given the firm's revenues. This question is addressed by altering the dependent variable of the first set of regressions such that the new dependent variable is the salesadjusted privatization price constructed by dividing the raw privatization price by the firm's sales and percentage of shares privatized. In this set of regressions attention is focused on how efficiency and market power measures like profits and profit margin (profit over sales) affect the salesadjusted privatization price as well as the effect of complete ownership. Complete ownership will be an important factor of the new owner's freedom in choosing its pricing policies and therefore its ability to take advantage of any market power that the firm might have.

Results for the complete sample are presented in Table $5 \mathrm{~A}$. The most striking result from the inter-industry study is that the differences in profit margins across firms stand out as an important determinant of the sales adjusted privatization prices (Regression 1). This result is consistent with that of Lopez-De-Silanes. To the extent that a state owned firm places a positive weight on its profits in its objective function, the current profit margin will be an indicator of the firm's potential market power and hence its ability to have a mark up over marginal cost once privatization takes place. Level of the firm's profits on the other hand is insignificant as before.

Capacity utilization rate is insignificant in Table 5A regressions while the privatization year is positive and significant indicating that there might be learning by government in the privatization process.

When we focus on a single industry - the cement industry - in Table 5B regressions, the efficiency and profitability measures are not found to be significant determinants of the sales-adjusted privatization prices. It is interesting to note that profit margin is no longer a significant determinant of the sales-adjusted privatization price though it was found to be significant in the multi-industry sample. Neither the profit margin (Regression 1) nor the level of 
Table 4B. Determinants of privatization prices $\uparrow:$ cement industry. Dependent variable: privatization price

\begin{tabular}{|c|c|c|c|c|c|c|c|}
\hline & (1) & (2) & (3) & (4) & (5) & (6) & (7) \\
\hline $\begin{array}{l}\text { Proportion } \\
\text { Privatized }\end{array}$ & $\begin{array}{c}165.40 * \\
(2.09)\end{array}$ & $\begin{array}{c}167.8^{* *} \\
(208)\end{array}$ & $\begin{array}{c}167.75^{*} \\
(182)\end{array}$ & $\begin{array}{c}153.82 * * \\
(2.19)\end{array}$ & $159.58 * *$ & $\begin{array}{c}164.74 * * \\
(228)\end{array}$ & $\begin{array}{c}166.01 * * \\
(254)\end{array}$ \\
\hline Production & $\begin{array}{l}0.0006^{* * *} \\
(3.98)\end{array}$ & $\begin{array}{l}0.0006^{* * *} \\
(4.01)\end{array}$ & $\begin{array}{l}0.0006^{* * * *} \\
(2.91)\end{array}$ & $\begin{array}{l}0.0007 * * * \\
(5.30)\end{array}$ & $\begin{array}{l}0.0007 * * * \\
(4.81)\end{array}$ & $\begin{array}{l}0.0009 * * * \\
(4.62)\end{array}$ & $\begin{array}{l}0.0008^{* * *} \\
(4.62)\end{array}$ \\
\hline $\begin{array}{l}\text { Production } \\
\quad \text { Growth rate }\end{array}$ & $\begin{array}{c}559.02 * \\
(1.92)\end{array}$ & $\begin{array}{c}580.08^{*} \\
(2.03)\end{array}$ & $\begin{array}{c}588.81^{*} \\
(1.81)\end{array}$ & $\begin{array}{l}551.26 * * \\
(2.14)\end{array}$ & $\begin{array}{c}571.96^{* *} \\
(2.08)\end{array}$ & $\begin{array}{c}590.75^{* *} \\
(2.67)\end{array}$ & $\begin{array}{c}590.97 * * \\
(2.81)\end{array}$ \\
\hline $\begin{array}{l}\text { Cap. Utilization } \\
\text { Ratio }\end{array}$ & $\begin{array}{l}-2.1382 * * \\
(-2.25)\end{array}$ & $\begin{array}{l}-2.14136 * * \\
(-2.18)\end{array}$ & $\begin{array}{l}-1.733 \\
(-1.41)\end{array}$ & & & & \\
\hline $\begin{array}{l}\text { Number of } \\
\text { Workers }\end{array}$ & $\begin{array}{l}-0.046 \\
(-0.16)\end{array}$ & & & & & & \\
\hline $\begin{array}{l}\text { Restructuring } \\
\text { Investment }\end{array}$ & & & & $\begin{array}{l}-0.006^{* *} \\
(-2.59)\end{array}$ & $\begin{array}{l}-0.005^{*} \\
(-1.91)\end{array}$ & $\begin{array}{l}-0.001 \\
(-0.25)\end{array}$ & \\
\hline Number of Bidders & & & & & & $\begin{array}{l}15.95 \\
(1.54)\end{array}$ & $\begin{array}{l}15.23^{*} \\
(1.73)\end{array}$ \\
\hline $\begin{array}{l}\text { The Length of } \\
\text { Auction }\end{array}$ & & & & & & & $\begin{array}{l}-0.0032 \\
(-0.02)\end{array}$ \\
\hline $\begin{array}{l}\text { Population } \\
\quad \text { Growth Rate }\end{array}$ & & & $\begin{array}{l}0.9688 \\
(0.87)\end{array}$ & $\begin{array}{c}1.32 \\
(1.26)\end{array}$ & $\begin{array}{c}1.41 \\
(1.37)\end{array}$ & & \\
\hline Privatization Year & & & $\begin{array}{c}1.322 \\
(0.11)\end{array}$ & & & & \\
\hline Profit & & $\begin{array}{l}0.00035 \\
(0.68)\end{array}$ & & & & & \\
\hline Intercept & $\begin{array}{r}-16327.2^{*} \\
(-2.07)\end{array}$ & $\begin{array}{r}-16589.5^{*} \\
(-2.06)\end{array}$ & $\begin{array}{r}-19252.9 \\
(-0.87)\end{array}$ & $\begin{array}{r}-19252.9 \\
(-0.87)\end{array}$ & $\begin{array}{r}-15964.3^{* *} \\
(-2.12)\end{array}$ & $\begin{array}{r}-16586.7 * * \\
(-2.32)\end{array}$ & $\begin{array}{r}-16704.5^{* * *} \\
(-2.58)\end{array}$ \\
\hline$R$-squared & 0.73 & 0.74 & 0.74 & 0.79 & $\mathrm{Na}$ & 0.88 & 0.88 \\
\hline $\begin{array}{l}\text { Number of } \\
\text { observations }\end{array}$ & 24 & 24 & 24 & 24 & 24 & 18 & 18 \\
\hline Estimation method & OLS & OLS & OLS & OLS & $2 \mathrm{SLS}$ & OLS & OLS \\
\hline
\end{tabular}

$\dagger$ Dependent variable is the privatization price in dollars corrected for inflation and scaled by 1000 .

$\mathrm{Na} R$-square is not an appropriate measure of goodness of fit with 2 SLS.

$t$-statistics are given in parentheses

*Significant at the $10 \%$ level

** Significant at the $5 \%$ level

****Significant at the $1 \%$ level

profits (Regression 2) is significant. Labour productivity, which is a measure of firm efficiency that can be used in these regressions due to the homogeneity of output within the cement industry, is also not significant (Regression 3). These results imply that differences in efficiency and profitability across public firms within the same industry do not have significant effects on the sales-adjusted privatization price. One of the variables that is used to measure profitability, profit margin, exhibits considerably greater variation in the complete sample than it does in the sample of cement firms. ${ }^{4}$

One would argue that profit margins measure the differences in market power of firms in different industries (market structures) rather than differences in firm efficiency and this is what is reflected in privatization prices in the results with the aggregate sample.
Differently from the aggregate sample regressions, the complete privatization dummy has a positive and significant effect and capacity utilization ratio has a negative and significant effect on the privatization price (Regressions 1 through 6). Thus, one can conclude that after controlling for firm's revenues, among firms operating at similar levels of profitability and efficiency, unexploited production opportunities and complete private ownership become the main determinants of privatization prices.

In Okten and Arin (2002), it is shown that after privatization, recently privatized cement firms lower prices and increase output, consistent with the argument in this study that potential buyers would value unexploited production opportunities (a low capacity utilization rate) if they plan to increase output after privatization. It appears

${ }^{4}$ From Tables 2 and 3, it is observed that the standard deviation of the profit margin is considerably higher for the complete sample. 
Table 5A. Determinants of privatization prices $\uparrow:$ complete sample. Dependent variable: sales adjusted privatization price

\begin{tabular}{|c|c|c|c|c|}
\hline & (1) & (2) & (3) & (4) \\
\hline \multirow{2}{*}{$\begin{array}{l}\text { Total Privatization } \\
\text { Dummy }\end{array}$} & 0.137 & -0.160 & -0.509 & 1.098 \\
\hline & $(0.19)$ & $(-0.19)$ & $(-0.46)$ & $(0.67)$ \\
\hline \multirow{2}{*}{$\begin{array}{l}\text { Profit Margin (Profit } \\
\text { Over Sales) }\end{array}$} & $3.336 * * *$ & $3.107 * *$ & & \\
\hline & $(3.04)$ & $(2.61)$ & & \\
\hline \multirow[t]{2}{*}{ Cap. Utilization Ratio } & 0.013 & & & \\
\hline & $(0.45)$ & & & \\
\hline \multirow[t]{2}{*}{ Privatization Year } & $0.272 *$ & $0.249^{*}$ & 0.263 & 0.110 \\
\hline & $(1.80)$ & $(1.80)$ & $(1.67)$ & $(0.64)$ \\
\hline \multirow[t]{2}{*}{ Profits } & & & 0.001 & \\
\hline & & & $(1.31)$ & \\
\hline \multirow{2}{*}{ Marina Dummy } & $28.388 * * *$ & $24.790 * * *$ & $21.75 * * *$ & $20.15 * * *$ \\
\hline & $(9.91)$ & $(6.92)$ & $(6.33)$ & $(5.59)$ \\
\hline \multirow[t]{2}{*}{ Port Dummy } & & 4.687 & 4.484 & 1.499 \\
\hline & & $(1.21)$ & $(1.20)$ & $(0.35)$ \\
\hline \multirow[t]{2}{*}{ Cement Dummy } & -1.050 & -1.866 & -2.357 & -4.855 \\
\hline & $(-0.83)$ & $(-1.19)$ & $(-1.19)$ & $(-1.52)$ \\
\hline \multirow[t]{2}{*}{ Dairy Dummy } & & & & $-6.428 *$ \\
\hline & & & & $(-1.94)$ \\
\hline \multirow[t]{2}{*}{ Intercept } & $-541.823^{*}$ & $-493.791 *$ & -521.682 & -213.708 \\
\hline & $(-1.78)$ & $(-1.78)$ & $(-1.65)$ & $(-0.61)$ \\
\hline$R$-squared & 0.94 & 0.88 & 0.84 & 0.80 \\
\hline Number of observations & 31 & 36 & 36 & 66 \\
\hline Estimation method & OLS & OLS & OLS & OLS \\
\hline
\end{tabular}

$\dagger$ Dependent variable is the privatization price divided by sales and percentage share privatized.

$t$-statistics are given in parentheses

* Significant at the $10 \%$ level

** Significant at the $5 \%$ level

*** Significant at the $1 \%$ level

that the cement industry is transformed from a government monopoly to a more competitive industry.

The same transition is not likely for other industries such as ports, and dairy industry and that may be why one does not find capacity utilization ratio to be significant in the inter-industry analysis. Government dairy firms faced considerable competition from the private sector before privatization. Ports and marinas on the other hand are more likely to be characterized with a monopolistic market structure that is likely to continue after privatization.

It is found that government's restructuring investment has no significant effects on the sales-adjusted privatization price (Regression 5). Number of bidders has a positive and significant effect and the length of the auction is an insignificant determinant of the sales-adjusted privatization price (Regressions 5 and 6).

\section{CONCLUDING THOUGHTS}

Since generating revenue for government is one of the primary reasons for privatizing public firms, it is important to better understand its determinants. Should the government engage in restructuring policies and investment prior to privatization? The answer to this question is negative.
Restructuring investment does not increase the sale price. Firms appear interested in buying a market and hence market and firm characteristics that affect revenues are important while current profits and costs are not. However, government's decision for complete privatization is of importance as one finds that firms that are privatized in total fetch a higher per share price.

Profit margin appears to be a significant and positive determinant of the sales-adjusted privatization price in the multi-industry study whereas this variable is not significant when one focuses on a single (cement) industry. This is due to the fact that profit margin is a measure of market power, which varies a great deal when one has firms from different industries with significantly different market structures in the sample. In a homogeneous oligopoly like the cement industry, firms are likely to have similar profit margins and hence this variable is no longer a significant determinant of the sales-adjusted privatization price.

More empirical studies are needed to analyse whether the relationship found for the cement industry between the privatization price and capacity utilization rate holds for other industries and how it is related to the market structure of the industry in question. Also needed are studies that examine how the privatization process variables and sale prices are related to post-privatization outcomes. 
Table 5B. Determinants of privatization prices $\dagger$ : cement industry. Dependent variable: sales adjusted privatization price

\begin{tabular}{|c|c|c|c|c|c|c|}
\hline & (1) & $(2)$ & (3) & (4) & $(5)$ & (6) \\
\hline $\begin{array}{l}\text { Complete Privatization } \\
\text { Dummy }\end{array}$ & $\begin{array}{l}1.171 * * * \\
(2.93)\end{array}$ & $\begin{array}{l}1.170^{* * *} \\
(2.93)\end{array}$ & $\begin{array}{l}1.042 * * * \\
(3.17)\end{array}$ & $\begin{array}{l}0.859^{* *} \\
(2.23)\end{array}$ & $\begin{array}{l}0.699^{*} \\
(2.07)\end{array}$ & $\begin{array}{l}0.714^{* *} \\
(2.16)\end{array}$ \\
\hline Profit Margin & $\begin{array}{l}-0.751 \\
(-0.75)\end{array}$ & & & & & \\
\hline Labour Productivity & & & $\begin{array}{l}0.0002 \\
(0.39)\end{array}$ & & & \\
\hline $\begin{array}{l}\text { Production } \\
\quad \text { Growth rate }\end{array}$ & $\begin{array}{r}0.039 \\
(0.04)\end{array}$ & $\begin{array}{c}0.058 \\
(0.07)\end{array}$ & $\begin{array}{l}0.0287 \\
(0.03)\end{array}$ & $\begin{array}{l}-0.212 \\
(-0.23)\end{array}$ & & \\
\hline Cap. Utilization Ratio & $\begin{array}{l}-0.039 * * * \\
(-3.28)\end{array}$ & $\begin{array}{l}-0.039 * * * \\
(-3.34)\end{array}$ & $\begin{array}{l}-0.037 * * * \\
(-3.75)\end{array}$ & $\begin{array}{l}-0.034^{*} \\
(-1.99)\end{array}$ & $\begin{array}{l}-0.030^{* * * *} \\
(-3.23)\end{array}$ & $\begin{array}{l}-0.0299 * * * \\
(-3.18)\end{array}$ \\
\hline Restructuring Investment & & & & & $\begin{array}{l}8.74 \mathrm{e}-06 \\
(0.43)\end{array}$ & \\
\hline Number of Bidders & & & & & $\begin{array}{l}0.273^{* *} \\
(2.51)\end{array}$ & $\begin{array}{l}0.278 * * \\
(2.54)\end{array}$ \\
\hline The Length of Auction & & & & & & $\begin{array}{l}0.0005 \\
(0.70)\end{array}$ \\
\hline Population Growth Rate & & & & $\begin{array}{l}-0.001 \\
(-0.09)\end{array}$ & & \\
\hline Privatization Year & & & & $\begin{array}{c}0.100 \\
(1.48)\end{array}$ & & \\
\hline Profit & & $\begin{array}{l}-5.43 \mathrm{e}-06 \\
(-0.75)\end{array}$ & & & & \\
\hline Intercept & $\begin{array}{l}4.766^{* * * *} \\
(4.67)\end{array}$ & $\begin{array}{l}4.725^{* * *} \\
(4.76)\end{array}$ & $\begin{array}{l}4.285^{* * *} \\
(4.14)\end{array}$ & $\begin{array}{r}-195.825 \\
(-1.44)\end{array}$ & $\begin{array}{l}3.489 * * * \\
(4.03)\end{array}$ & $\begin{array}{l}3.340^{* * *} \\
(3.65)\end{array}$ \\
\hline$R$-squared & 0.60 & 0.59 & 0.58 & 0.60 & 0.78 & 0.79 \\
\hline Number of observations & 23 & 23 & 23 & 23 & 18 & 18 \\
\hline Estimation method & OLS & OLS & OLS & OLS & OLS & OLS \\
\hline
\end{tabular}

$\dagger$ Dependent variable is the privatization price divided by sales and percentage share privatized.

$t$-statistics are given in parentheses

* Significant at the $10 \%$ level

** Significant at the $5 \%$ level

$* * *$ Significant at the $1 \%$ level

After all, if the privatization process is itself flawed, it is doubtful that the privatized firms will perform better than state owned enterprises.

\section{ACKNOWLEDGEMENTS}

We would like to thank Esin Uygur, Tamer Akinozu, Ahmet Altintig, Ozal Yuzugullu, Ozgur Bor, Gokhan Aykut and Suna Bulur for providing the data set. We would also like to thank Ayca Altintig, Kevin Hasker, Geoffrey Turnbull and Burton A. Weisbrod for their valuable comments. Of course, all errors are our own.

\section{REFERENCES}

Altman, E. (1984) A further empirical investigation of the bankruptcy cost question, Journal of Finance, 34, 1067-89.

Caves, R. (1990) Lessons from privatization in Britain: state enterprise behavior, public choice and corporate governance, Journal of Economic Behavior and Organization, 13, $145-69$.
Ertuna O. (1998) Constraints of privatization: the Turkish case. Working Paper, Bogazici University.

Ficici A. (2001) Political economy of Turkish privatization: a critical assessment. Working Paper, New Hampshire College.

Huang, Q. and Levich, R.M. (1998) Underpricing of new equity offerings by privatized firms: an international test. New York University Working Paper.

Laffont, J. (1994) Regulation, privatization and incentives in developing countries. Paper prepared for the ADB Conference on Development Economics in Manila.

Lopez-De-Silanes, F. (1997) Determinants of privatization prices, Quarterly Journal of Economics, 112, 965-1025.

Megginson, W. and Netter, J. (2001) From state to market: a survey of empirical studies on privatization, Journal of Economic Literature, 39, 321-89.

Milgrom, P.R. (1987) Auction Theory, Advances in Economic Theory: Fifth World Congress 1-32 Publication: Econometric Society Monographs Series, No. 12, Cambridge University Press, Cambridge, New York and Melbourne.

Okten, C. and Arin, K.P. (2002) The effects of privatization on efficiency, productivity and technology choice: evidence from Turkey. Bilkent University Working Paper. 
Orta Anadolu Ihracatcilar Birligi (1998) Cimento Sektoru Raporu (Cement Industry Report), Central Anatolian Board of Export.

Ozellestirme Idaresi Baskanligi (Privatization Administration) (2000) Privatization in Turkey.

Saygili, S. and E. Taymaz (2001) Privatization, ownership and technical efficiency: a study of the Turkish Cement Industry, Annals of Public and Cooperative Economics, 74, 581-605.

Tallant, D. (1993) Relative efficiency of public and private sector ownership and privatization of the Turkish cement industry, Review of Social, Economic and Administrative Studies, 7, 73-103.

White, H. (1980) A heteroskedasticity-consistent covariance matrix estimator and a direct test for heteroskedasticity, Econometrica, 48, 817-38.

Wruck, K. (1990) Financial distress, reorganization and organizational efficiency, Journal of Financial Economics, 27, 41944. 